Volume 1 Issue 2, September 2017: pp. 167-179. Copyright (c) 2017 HOLREV. Faculty of Law, Halu Oleo University, Kendari, Southeast Sulawesi, Indonesia. ISSN: 2548-1762 | e-ISSN: 2548-1754. Open Access at: http://ojs.uho.ac.id/index.php/holrev/

Halu Oleo Law Review is licensed under a Creative Commons Attribution 4.0 International License, which permits unrestricted use, distribution, and reproduction in any medium, provided the original work is properly cited.

\title{
Implementasi Prinsip Negara Hukum dan Demokrasi Dalam Pembentukan Peraturan Daerah
}

\author{
Implementation on Principle of Legal State and Democracy in the Frame of \\ Local Ordinance
}

\author{
Nasrullah Muhammadong \\ Dosen Fakultas Hukum Universitas Tadulako (Untad), Palu \\ E-mail: nasrullahmuhammadong@yahoo.com
}

\begin{abstract}
This paper starting from the theoretical study of some of the variables, namely, the principle of "rule state" and "democracy". Furthermore, it examines the normative aspects of "Formation of local regulation", with the aim at finding the correlation with some of the variables.

Relating to the principle of rule state, there are some matters that became of object of study, namely: aspects of legality principle. In relation to the formulation of local regulation, it rightly be formed which is appropriating to the matter of regulation, procedural in its ordinance, and the authority to enact a law according to its form. While, relating to the aspects of hierarchy of laws and regulations, local regulation placed in the lowermost over the all regulations. It eventually was have implication to the matter of local regulation intended as such.

One of the most urgent elements in the process of forming the law, namely, element of openness. Therefore, the formulation of local regulation which is started with planning, drafting, discussion, endorsement or determination, and promulgation must be transparent or open. This is meant that all people have opportunity as much as possible to response and giving feedback in the formulation of local regulation.
\end{abstract}

Keyword: state law, democracy, and local regulation.

Abstrak: Tulisan ini, dimulai dari kajian teoritis dari beberapa variabel dari judul tulisan ini, yakni, prinsip "negara hukum" dan "demokrasi". Selanjutnya menelaah aspek normatif dari "Pembentukan Perda", dengan tujuan mencari korelasi dengan beberapa variabel tadi.

Untuk prinsip negara hukum, beberapa unsur yang menjadi obyek kajiannya, yaitu: pertama: aspek asas legalitas. Dalam kaitannya dengan masalah Pembentukan Perda, yaitu telah diaturnya kesesuaian bentuk Perda, dengan materi yang diatur; aspek prosedural dalam tata cara pembuatannya: dan kewenangan untuk menetapkan Perda sesuai dengan bentuknya. Kedua: aspek hierarki peraturan perundang-undangan. Perda diberi kedudukan paling di bawah dari semua peraturan yang diterbitkan ditingkat pusat, yang pada akhirnya, aspek hierarki ini, 
berimplikasi pula pada aspek materi muatan Perda dimaksud.

Untuk prinsip "Demokrasi". Salah satu unsurnya yang paling urgen dalam proses

pembentukan Perda, yakni: unsur "keterbukaan". Pembentukan Perda, yang di mulai dari perencanaan, penyusunan, pembahasan, pengesahan atau penetapan, dan pengundangan, harus bersifat transparan atau terbuka. Dengan demikian, seluruh lapisan masyarakat mempunyai kesempatan yang seluas-luasnya untuk memberikan masukan dalam Pembentukan Perda itu sendiri.

Kata kunci: negara hukum, demokrasi, dan peraturan daerah.

\section{PENDAHULUAN}

Di bagian menimbang (huruf c) Undang-Undang Nomor 12 Tahun 2011 Tentang Pembentukan Peraturan Perundang-Undangan,1 disebutkan: "bahwa dalam UndangUndang Nomor 10 Tahun 2004 tentang Pembentukan Peraturan Perundang-undangan masih terdapat kekurangan dan belum dapat menampung perkembangan kebutuhan masyarakat mengenai aturan pembentukan peraturan perundangundangan yang baik sehingga perlu diganti". ${ }^{2}$

Berkaitan dengan tulisan ini, mengapa soal Pembentukan Perda menarik untuk dikaitkan dengan prinsip negara hukum dan demokrasi? Untuk menjawabnya, tentu diawali dengan sebuah pemahaman awal.

Sebagaimana diketahui, negara yang dirikan dan dibangun oleh para founding father ini, adalah negara yang dibangun di atas prinsip negara hukum. ${ }^{3}$ Dalam konsep negara hukum itu sendiri, terdapat beberapa unsur di dalamnya. Di antaranya (dan ini juga menjadi obyek kajian tulisan ini) ${ }^{4}$, Pertama: unsur menjalankan peraturan berdasarkan asas legalitas dan kepastian hukum. Unsur ini, sangat berkaitan pula dengan sistem hukum

1 Untuk kepentingan praktis penulisan, undang-undang ini, selanjutnya disingkat saja dengan UU No 12/2011. Dan penulisan undang-undang, disingkat menjadi UU.

2 Memang banyak hal yang baru dan cukup substansial dari UU No 12/2011 tersebut. Mengenai Program Legislasi Daerah (Prolegda), misalnya. Tata cara penyusunan dan pengelolaan Prolegda, dalam UU ini telah diatur secara khusus, yang oleh UU sebelumnya tidak diatur. Belum lagi soal jenis peraturan yang bernama Peraturan Desa. UU No 12/2011 tidak lagi mengkategorikannya sebagai bagian dari Perda. Bahkan telah dihapus dari hierarki peraturan perundang-undangan.

3 Dalam Pasal 1 ayat (3) UUD 1945 ditegaskan: "Negara Indonesia adalah negara hukum". Ketentuan tersebut berasal dari penjelasan UUD 1945 yang melalui proses amandemen "diangkat" ke dalam "batang tubuh" UUD 1945.

4 Prinsip negara hukum, unsur-unsurnya, sebenarnya, dapat dibedah secara keseluruhan, yang kemudian dicari benang merahnya dengan norma yang mengatur tentang Pembentukan Perda tersebut. Namun penulis hanya lebih mem-fokuskan kajian pada tiga unsurnya saja, dengan pertimbangan, ketiga unsur tersebut, lebih dekat dengan permasalahan atas proses Pembentukan Perda itu sendiri. Juga penguraian atas prinsip demokrasi. Pilihan atas unsur-unsurnya untuk dikaitkan dengan Pembentukan Perda, sama pula dengan pertimbangan penulis atas soal yang di awal tadi. 
yang berlaku di negara kita, yakni sistem eropa kontinental, yang salah satu karakteristiknya adalah pembentukan "hukum tertulis" dan "ketertiban hukum".

Unsur kedua, adanya hierarki peraturan perundang-undangan. Sejak diamandemennya UUD 1945, uji materiil semakin diberikan penguatan. Misalnya, lahirnya lembaga Mahkamah Konstitusi, yang salah satu kewenangannya yaitu melakukan uji materiil, yang sebelumnya hanya dimiliki oleh Mahkamah Agung. Dan yang terkini, yaitu, pemerintah pusat. Melalui Menteri Dalam Negeri-nya, dapat membatalkan Perda, bila berdasarkan hasil pengujian, ada Perda yang dianggap bertentangan dengan peraturan di atasnya.

Dan unsur ketiga-dan ini tak kalah pentingnya, karena telah menjadi salah satu isu global-yakni, unsur perlindungan Hak Asasi Manusia (HAM).

Unsur-unsur sebagaimana tersebut di atas, oleh penulis coba di-elaborasi, yang pada akhirnya akan menuju pada sebuah pertanyaan akhir: "apakah unsur-unsur tadi, ada terimplementasikan secara normatif, khususnya dalam instrumen hukum yang turut mengatur tentang Pembentukan Perda itu sendiri?"

Selanjutnya, bagaimana pula dengan prinsip "demokrasi" sebagaimana yang tersebut juga dalam judul di atas? Prinsip ini menjadi menarik pula untuk dikaji sehubungan dengan Pembentukan Perda. Dengan pertimbangan, bahwa gagasan "demokrasi" itu sendiri, di antaranya, mewajibkan, agar setiap Pembentukan Perda, ikut memartisipasikan masyarakat dalam proses pembuatannya, baik dari tahap perancangan, pembahasan, hingga tahap penyebarluasannya. Ke semua tahap ini, akan bermuara kepada "satu tujuan" yakni, terlaksananya "asas keterbukaan" dalam penyelenggaraan negara.

\section{ANALISIS DAN PEMBAHASAN}

\section{Prinsip Negara Hukum}

Secara umum, negara hukum dapat diartikan sebagai negara di mana tindakan pemerintah maupun rakyatnya didasarkan atas hukum untuk mencegah adanya tindakan sewenang-wenang dari pihak pemerintah dan tindakan rakyat yang dilakukan menurut kehendaknya sendiri. ${ }^{5}$

5 Bintan R. Saragih, Peranan DPR GR Periode 1965-1971 dalam Menegakkan Ketatanegaraan yang Konstitusional Berdasarkan UUD 1945, Disertasi, Bandung: Universitas Padjadjaran, 1991, h. 11. 
Beberapa teori yang menjelaskan konsep negara hukum yaitu teori rechtsstaat dan rule of law. Konsep rechtsstaat bertumpu atas sistem hukum kontinental yang disebut civil law, sedangkan konsep the rule of law bertumpu atas sistem hukum yang disebut common law. Karakteristik civil law adalah administratif, sedangkan karakteristik common law adalah judicial. ${ }^{6}$

Dari latar belakang dan dari sistem hukum yang menopangnya memang terdapat perbedaan antara rechtsstaat dengan konsep the rule of law, meskipun dalam perkembangan dewasa ini tidak dipermasalahkan lagi perbedaan antara keduanya. Karena pada dasarnya kedua konsep itu mengarahkan dirinya pada satu sasaran yang utama yaitu pengakuan dan perlindungan terhadap hak-hak asasi manusia. Meskipun dengan sasaran yang sama tetapi keduanya tetap berjalan dengan sistem sendiri yaitu sistem hukum sendiri. ${ }^{7}$

Konsep rechtsstaat yang, sekali lagi, berlaku di Eropa Kontinental (dan termasuk pula berlaku dalam sistem hukum Indonesia) ${ }^{8}$ yang mempunyai ciri-ciri sebagai berikut:

a. perlindungan hak-hak asasi manusia;

b. pemisahan atau pembagian kekuasaan untuk menjamin hak itu;

c. pemerintah berdasarkan peraturan-peraturan; dan

d. peradilan administrasi dalam perselisihan. ${ }^{9}$

Menarik pula konsep negara hukum sebagaimana yang dikemukakan oleh A. Hamid Attamimi. Menurut beliau: "Paham negara yang berdasarkan atas hukum, mendasarkan pengertian secara substantif berpangkal dari beberapa asas. Salah satu di antaranya adalah negara yang penyelenggaraannya dilakukan dengan memperhatikan peraturan perundang-undangan yang pembuatannya berlangsung

\footnotetext{
Philipus M. Hadjon, Perlindungan Hukum Bagi Rakyat di Indonesia, Surabaya: Bina Ilmu 1987, h. 72. Ibid.

8 Menurut Padmo Wahyono, dalam kepustakaan Indonesia, istilah negara hukum merupakan terjemahan langsung dari rechtsstaat. (Padmo Wahjono, Ilmu Negara Suatu Sistematik dan Penjelasan 14 Teori Ilmu Negara dari Jellinek, Jakarta: Melati Study Group, 1977, h. 30).

9 Oemar Seno Adji, Seminar Ketatanegaraan Undang-Undang Dasar 1945, Jakarta: PT. Seruling Masa, 1966, hal.24. Bandingkan pula dengan konsep Rule of Law yang diperkenalkan oleh A.V. Dicey, yang memiliki ciri-ciri sbb: a. Supremasi aturan-aturan hukum (supremacy of the law) tidak adanya kekuasaan sewenang-wenang (absence of arbitrarypower) dalam arti, seseorang hanya boleh dihukum kalau melanggar hukum; b. Kedudukan yang sama dalam menghadapi hukum (equality before of the law); dan c. Terjaminnya hak asasi manusia oleh undang-undang dasar, serta keputusan-keputusan pengadilan.
} 
dengan memperhatikan cita hukum bangsa Indonesia, dan tersusun dengan jenjang atas hierarki yang pasti". ${ }^{10}$

Sejalan dengan pendapat di atas, J.Z. Laudoe, pun menegaskan: “Disiplin hukum telah menggarisbawahi empat unsur inheren dari negara hukum: 1. Asas legalitas; 2. Pemisahan kekuasaan; 3. Jaminan Hak asasi manusia; 4. Pengawasan atas wewenang menguji oleh hakim (judicial review) terhadap tindakan penguasa". Lebih lanjut dijelaskan: "Bila wewenang menguji berfungsi sebagai peluang bagi para yustisia-belen menghadapkan masalah tidak sahnya suatu tindakan penguasa untuk diuji, maka asas legalitas mengandung perintah bahwa setiap tindakan penguasa tersebut bersumber pada ketentuan perundang-undangan formil atas UUD". ${ }^{11}$

Dari berbagai pandangan atas unsur-unsur negara di atas, yang sangat relevan untuk kita bahas dalam kaitannya dengan proses pembentukan Perda, yaitu:

1. Asas Legalitas dan Prinsip kepastian hukum;

2. Aturan berdasarkan jenjang atau hierarki; dan

3. Perlindungan HAM.

\section{Asas legalitas dan Prinsip kepastian hukum ${ }^{12}$}

Sekadar pemahaman awal. Secara teoritis dan yuridis asas legalitas itu dapat diperoleh melalui atributif-legislator, baik yang berada di tingkat pusat maupun di daerah. Di tingkat pusat, misalnya. Asas legalitas melalui atributif-legislator itu dapat diperoleh melalui MPR, dalam wujud UUD yang dihasilkannya. Dan sebaliknya, di tingkat Daerah, dapat diperoleh dari pemerintahan daerah, melalui pembentukan Perda, misalnya. Wewenang dari lembaga-lembaga tadi dalam membentuk hukum tertulis (baca: asas legalitas), inilah yang disebut original legislator atau berasal dari pembuat undangundang asli (originale wetgever).

Kembali ke soal Asas legalitas dan Prinsip kepastian hukum dalam pembentukan Perda itu sendiri.

10 Dalam Bambang Kesowo, “Implementasi Prinsip Supremasi Hukum dalam Berbagai Produk Hukum Nasional”, Makalah Temu Ilmiah ISMAHI, Unhas, Makassar, 25 Oktober, 1994, h. 3.

11 J.Z. Laudoe, Judicial Review: Sistem Perlindungan Hukum Terhadap tindakan Penguasa, Majalah Varia Peradilan, No. 84/Tahun IX/Sep.1995, h. 149.

12 Hubungan antara asas legalitas dengan kepastian hukum, dapat dibaca dari pendapat Indroharto, bahwa: "Penerapan asas legalitas, akan menunjang berlakunya kepastian hukum dan berlakunya kesamaan perlakuan. (Indroharto, "Perbuatan Pemerintah Menurut Hukum Publik dan Hukum Perdata" Bahan Kuliah/Diktat pada Program Pendidikan Lanjutan Ilmu Hukum Bidang PTUN, Universitas Indonesia, Jakarta, 1992, h. 7). 
Pasal 6 ayat (1) huruf i UU No 12/2011, menegaskan:

"Materi muatan Peraturan Perundang-undangan harus mencerminkan asas: "ketertiban dan kepastian hukum".13

Dalam penjelasannya:

"Yang dimaksud dengan "asas ketertiban dan kepastian hukum" adalah bahwa setiap Materi Muatan Peraturan Perundang-undangan harus dapat mewujudkan ketertiban dalam masyarakat melalui jaminan kepastian hukum".

Dari uraian pasal di atas, dapat dipahami, bahwa Perda sekali lagi, sebagai salah satu bentuk peraturan perundang-undangan, dapat melaksanakan social control dalam kehidupan masyarakat. Untuk mewujudkan itu, aspek kepastian hukum dalam substansinya tak boleh disepelekan. Apalagi Perda, instrumen hukum yang langsung menukik kepada penyelesaian masalah kehidupan rakyat daerah secara nyata, tak boleh ada kesimpangsiuran aturan atau norma yang tumpang tindih di dalamnya. Juga dalam soal jaminan kepastian hukum. Dalam penerapan Perda, tetap mengedepankan asas legalitas. Pelanggaran atas asas ini, sudah tentu akan mengoyak rasa keadilan masyarakat, dan di sisi lain, akan menciptakan kesewenang-wenangan pemerintah daerah melalui kebijakan yang dibuatnya.

Intinya, memahami relevansi (penerapan) asas legalitas dan prinsip kepastian hukum dalam pembentukan Perda, hemat penulis, secara umum dimulai dari: pertama, diakuinya Perda (khususnya melalui UU No 12/2011), sebagai salah satu instrumen hukum tertulis ditingkat daerah; Adapun secara khusus, yakni:

Pertama, adanya ketentuan yang mengatur tentang kesesuaian bentuk dan jenis peraturan daerah dengan materi yang diatur;

Kedua, adanya ketentuan yang mengatur aspek prosedural dalam tata cara pembuatannya: dan

Ketiga, adanya ketentuan yang mengatur tentang kewenangan, yaitu Peraturan Daerah ditetapkan oleh Kepala Daerah dengan persetujuan DPRD, yang merupakan representasi dari rakyat yang diwakilinya.

13 UU No 12/2011, menegaskan pula, bahwa materi muatan Perda selain mencerminkan beberapa asas lain sebagaimana yang telah disebutkan dalam ayat (2), Perda tertentu dapat pula berisi asas lain sesuai dengan bidang hukum Perda yang bersangkutan. Asas lain yang dimaksud, di antaranya, dalam Hukum Pidana, yang digunakan adalah asas legalitas, asas tiada hukuman tanpa kesalahan, asas pembinaan narapidana, dan asas praduga tak bersalah (Lihat: Pasal 6 ayat [2] beserta penjelasannya). 


\section{Aturan berdasarkan jenjang atau hierarki ${ }^{14}$}

Untuk memberikan perlindungan konstitusional terhadap rakyat, dalam suatu negara hukum tentu pula wajib memperhatikan korelasi atau sinkronisasi dari berbagai produk peraturan perundang-undangan yang berlaku. Khusus dalam Penyusunan Perda, para pembentuk dituntut untuk memerhatikan hierarki atau susunan dari peraturan yang ada. Bila tidak, hal ini hanya menciptakan suasana ketidaktertiban hukum, pun akan menggoyahkan rasa keadilan masyarakat. ${ }^{15}$

Dalam UU No 12/2011, Perda dimasukkan sebagai salah satu bentuk peraturan perundang-undangan dalam sebuah hierarki. Hal ini dapat dipahami melalui Pasal 7 ayat (1):

"Jenis dan hierarki Peraturan Perundang-undangan terdiri atas:
a. Undang-Undang Dasar Negara Republik Indonesia Tahun 1945;
b. Ketetapan Majelis Permusyawaratan Rakyat;
c. Undang-Undang/Peraturan Pemerintah Pengganti Undang-Undang;
d. Peraturan Pemerintah;
e. Peraturan Presiden;
f. Peraturan Daerah Provinsi; dan
g. Peraturan Daerah Kabupaten/Kota".

Pemahaman bahwa penerapan Perda harus berdasarkan jenjang atau aturan yang berlaku, tentu berimplikasi pula kepada materi muatan peraturan itu sendiri. Pasal 5 Huruf c dalam penjelasannya, menegaskan:

"Yang dimaksud dengan "asas kesesuaian antara jenis, hierarki, dan materi muatan" adalah bahwa dalam Pembentukan Peraturan Perundang-undangan harus benar-

14 Hierarki, salah satu pengertiannya, yaitu: "urutan tingkatan atau jenjang jabatan", (W.J.S., Poerwadarminta, Kamus Umum Bahasa Indonesia, Edisi Ketiga, Cet. 4, Jakarta: Balai Pustaka, 2007, h. 418). Ajaran tentang norma berdasarkan hierarki atau tingkatan, diperkenalkan oleh Hans Kelsen. Pada tahun 1934 ia menerbitkan tulisan tentang Teknik dan Hukum Acara Internasional, serta karya monumental yang terkenal tentang "Ajaran Hukum Murni" (Reine Rechtslehre) yang mencakup pokokpokok pikiran di bidang Hukum Internasional. Antara lain yang dibahas di dalamnya mengenai lapisan bertingkat/hierarki (Stueffenbau) norma-norma Hukum Internasional dan Norma Dasar (Grundnorm).

15 Sebanyak 67 Perda Kabupaten/Kota di Sulteng, dibatalkan dan dicabut oleh Mendagri. Selain karena bertentangan dengan aturan yang lebih tinggi, sebagian Perda dicabut, karena disusun dan ditetapkan tanpa melalui prosedur. Gubernur Sulteng, Longki Djanggola menyatakan, puluhan Perda yang dicabut tersebut sebagian besar merupakan Perda yang mengatur tentang pungutan pajak dan retribusi. Sebagian Perda tersebut juga dinilai menghambat investasi dan pertumbuhan usaha kecil dan menengah. Perda-perda itu dibatalkan antara Tahun 2003 hingga 2009. Rata-rata Perda tersebut diterbitkan dan berlaku antara tahun 2000 hingga 2005 (Dirangkum dari Harian Mercusuar, 23 September 2011). 
benar memperhatikan materi muatan yang tepat sesuai dengan jenis dan hierarki Peraturan Perundang-undangan".

Berikut, sekadar catatan tambahan penulis, tentang materi muatan itu sendiri. Karena, sekali lagi, hal ini sangat berkorelasi dengan pemahaman hierarki atau kedudukan atas Perda itu sendiri (lihat kembali penjelasan pasal 5 Huruf c, sebagaimana tersebut di atas).

UU No 12/2011 menyebut materi muatan Perda melalui Pasal 14, yang dinyatakan:

"Materi muatan Peraturan Daerah Provinsi dan Peraturan Daerah Kabupaten/Kota berisi materi muatan dalam rangka penyelenggaraan otonomi daerah dan tugas pembantuan serta menampung kondisi khusus daerah dan/atau penjabaran lebih lanjut Peraturan Perundang-undangan yang lebih tinggi".

Undang-undang di atas, tidak mengulas apa yang harus terkandung dalam materi muatan Perda Provinsi maupun Kabupaten/Kota. Dalam penjelasannya hanya dikatakan: "cukup jelas".

Tapi pandangan dari Prof. Dr. I Gde Pantja Astawa, SH.MH, berikut ini, sedikit membantu kita untuk memahami soal itu, yakni sebagai berikut: 16

Pertama: Perda Provinsi, materi muatannya adalah:

1. Kewenangan yang diperoleh dalam bidang ekonomi yang berisikan kewenangan yang bersifat lintas kabupaten/kota, kewenangan di bidang pemerintahan tertentu, dan kewenangan yang tidak atau belum dapat dilaksanakan oleh kabupaten/kota;

2. Berdasarkan penjabaran lebih lanjut dari peraturan perundang-undangan di atasnya, termasuk tugas pembantuan;

3. Untuk menampung dan mengekspresikan kondisi khusus di daerah yang lintas kabupaten/kota

Kedua: Perda Kabupaten/Kota, materi muatannya adalah:

1. Kewenangan yang diperoleh untuk melaksanakan otonomi daerah yang berisikan kewenangan wajib dan kewenangan pilihan;

2. Berdasarkan penjabaran lebih lanjut dari peraturan perundang-undangan di atasnya, termasuk tugas pembantuan.

Untuk menampung dan mengekspresikan kondisi khusus di daerah.

16 I Gede Pantja Astawa dan Suprin Na'a, Dinamika Hukum dan Ilmu Perundang-Undangan Di Indonesia, Bandung: PT. Alumni, 2008, h. 105. 


\section{Perlindungan HAM17}

Dinyatakan dalam Pasal 6 ayat (1) huruf b, UU No 12/2011:

Materi muatan Peraturan Perundang-undangan harus mencerminkan asas "kemanusiaan"

Dalam penjelasannya, diuraikan:

Yang dimaksud dengan "asas kemanusiaan" adalah bahwa setiap materi muatan peraturan perundang-undangan harus mencerminkan pelindungan dan penghormatan hak asasi manusia serta harkat dan martabat setiap warga negara dan penduduk Indonesia secara proporsional.

Dari bunyi pasal di atas, dapatlah dipahami, bahwa materi muatan setiap Perda, spiritnya tetap memberikan pelindungan dan penghormatan atas hak asasi manusia.

Buku Panduan Praktis Memahami Perancangan Perda, yang disusun oleh Direktorat Jenderal Peraturan Perundang-undangan Departemen Hukum dan Hak Asasi Manusia R.I. (tahun 2008), pada halaman 209, melampirkan hasil penelitian di bawah judul: "Pengintegrasian Prinsip HAM dalam Penyusunan Peraturan Daerah". Hasil penelitian itu membagi 23 jenis urusan, yang kemudian disertai penjelasan, tentang muatan HAM apa saja yang penting diintegrasikan dalam penyusunan Perda.

Berikut, penulis akan sajikan satu contoh saja dari 23 jenis urusan dimaksud. ${ }^{18}$ Yakni, jenis urusan tentang Perumahan. Adapun muatan HAM yang diintegrasikan ke dalamnya, adalah, sbb:

1. Adanya Perda yang memuat kebijakan untuk menyediakan fasilitas bantuan pembiayaan perumahan bagi masyarakat dalam memenuhi kebutuhan bertempat tinggal dan berkehidupan yang layak.

2. Adanya Perda yang memuat Kebijakan penyediaan sarana, prasarana, dan utilitas publik yang memadai di seluruh kawasan perumahan tanpa terkecuali.

17 Di era reformasi, penghormatan dan pemajuan HAM mengalami perkembangan yang signifikan ditandai dengan keberadaan TAP MPR XVII/MPR/1998 tentang Hak Asasi Manusia, UU No 39 Tahun 1999 tentang Hak Asasi Manusia, UU No 26 Tahun 2000 Tentang Pengadilan Hak Asasi Manusia dan diratifikasinya sejumlah konvensi tentang HAM.

18 Ke-23 jenis urusan dimaksud, yang juga menjadi rujukan bagi semua Perda dalam rangka mengintegrasikan perlindungan HAM di dalamnya, yaitu: 1. Pendidikan; 2. Kesehatan; 3. Pekerjaan Umum; 4. Penataan Ruang; 5. Lingkungan Hidup; 6. Perumahan; 7. Kepemudaan dan Olahraga; 8. Penanaman Modal; 9. Koperasi dan Usaha Kecil dan Menengah; 10. Kependudukan dan Catatan Sipil; 11. Ketenagakerjaan; 12. Pertanian dan Ketahanan Pangan; 13. Pemberdayaan Perempuan dan Perlindungan Anak; 14. Keluarga Berencana dan Keluarga Sejahtera; 15. Perhubungan; 16. Komunikasi dan Informatika; 17. Pertanahan; 18. Kesatuan bangsa dan Politik dalam Negeri; 19. Otonomi Daerah, Pemerintahan Umum, dan Administrasi Keuangan Daerah; 20. Pemberdayaan masyarakat dan Desa; 21. Sosial dan kebudayaan; 22. Statistik, Kearsipan, dan Perpustakaan; dan 23. Perencanaan Pembangunan 
3. Adanya Perda yang memuat kebijakan penyediaan fasilitas perumahan dalam berbagai bentuk (rumah sederhana, rumah susun, dll.) dalam memenuhi kebutuhan tempat tinggal masyarakat.

\section{Berbagai Instrumen Hukum Yang Mengatur tentang BLU}

Pengertian "demokrasi” itu sendiri, mengandung dua arti, yakni: pertama, demokrasi yang dikaitkan dengan sistem pemerintahan yaitu bagaimana caranya rakyat diikut sertakan dalam penyelenggaraan pemerintahan; dan kedua, demokrasi sebagai asas, yang dipengaruhi keadaan kultural atau historis suatu bangsa. ${ }^{19}$

Asas-asas demokratis yang melandasi rechtsstaat, menurut S.W. Couwenberg meliputi 5 asas, yaitu: ${ }^{20}$

1. asas hak-hak politik (het beginsel van de politieke grondrechten);

2. asas mayoritas;

3. asas perwakilan;

4. asas pertanggungjawaban;

5. asas publik (openbaarheidsbeginsel).

Begitu pula Prof. Mr. M.C. Burkens, et al., dalam buku berjudul "Beginselen van de democratische rechtsstaat", secara singkat dipaparkan tentang syarat minimum demokrasi adalah:

1. pada dasarnya setiap orang mempunyai hak yang sama dalam pemilihan yang bebas dan rahasia;

2. pada dasarnya setiap orang mempunyai hak untuk dipilih;

3. setiap orang mempunyai hak-hak politik berupa hak atas kebebasan berpendapat dan berkumpul;

4. Badan Perwakilan Rakyat mempengaruhi pengambilan keputusan melalui sarana "(mede) beslissings recht" (hak untuk ikut memutuskan) dan atau melalui wewenang pengawas;

6. asas keterbukaan dalam pengambilan keputusan dan sifat keputusan yang terbuka; dan 
7. dihormatinya hak-hak kaum minoritas. ${ }^{21}$

Yang menarik untuk dikaji dari beberapa syarat minimum demokrasi di atas, yaitu (tentang) "asas keterbukaan dalam pengambilan keputusan dan sifat keputusan yang terbuka".

Asas keterbukaan merupakan salah satu elemen dari prinsip demokrasi dewasa ini. Apalagi di era globalisasi/informasi sekarang ini, hal itu telah menjadi sebuah tuntutan. Khususnya dalam proses pembentukan Perda. Berbicara tentang peran serta masyarakat, tanpa disertai pelaksanaan asas keterbukaan, mustahil akan tercipta yang namanya "Perda Partisipatif".

Dan asas "keterbukaan" ini, kalau kita membaca dalam UU No 12/2011, juga salah satu dari 7 (tujuh) butir asas pembentukan peraturan perudang-undangan sebagaimana yang dapat dibaca pada Pasal 5 huruf g:

Dalam membentuk Peraturan Perundang-undangan harus dilakukan berdasarkan pada asas Pembentukan Peraturan Perundang-undangan yang baik, yang meliputi: (antara lain, pen.) "keterbukaan".

Dalam penjelasannya:

Yang dimaksud dengan "asas keterbukaan" adalah bahwa dalam Pembentukan Peraturan Perundang-undangan mulai dari perencanaan, penyusunan, pembahasan, pengesahan atau penetapan, dan pengundangan bersifat transparan dan terbuka. Dengan demikian, seluruh lapisan masyarakat mempunyai kesempatan yang seluasluasnya untuk memberikan masukan dalam Pembentukan Peraturan Perundangundangan.

Aspek Demokrasi atau keterbukaan, dalam penyusunan Perda, dalam UU No 12/2011, diperintahkan sejak dimulainya penyusunan Promperda. ${ }^{22}$ Sebagai contoh, yakni dalam penyusunan Promperda Provinsi. Dinyatakan, bahwa dalam penyusunan daftar rancangan peraturan daerah provinsi didasarkan atas (antara lain, pen): aspirasi masyarakat daerah. ${ }^{23}$ Setelah disusun, Promperda tersebut disebarluaskan lagi kepada

21 Dalam Philipus M. Hadjon, Keterbukaan Pemerintah dan Tanggung Gugat Pemerintah, Makalah Seminar Hukum Nasional ke-VI, tema Reformasi Hukum Menuju Masyarakat Madani, Jakarta: Badan Pembinaan Hukum Nasional Departemen Kehakiman R.I, 12-15 Oktober 1999; h. 3.

22 Promperda singkatan dari Program Pembentukan Perda (lihat Pasal 403 UU No 23/2014 tentang Pemerintahan Daerah). Sebelumnya diberi nama "Program Legislasi Daerah atau disingkat Prolegda oleh UU No. 12/2011. Menurut Pasal 1 butir 5 UU No 12/2011, Program Legislasi Daerah yaitu instrumen perencanaan program pembentukan Perda yang disusun secara terencana, terpadu, dan sistematis.

23 Lihat Pasal 35 huruf d UU No 12/2011. 
masyarakat untuk dapat memberikan informasi dan/atau memperoleh masukan masyarakat dan para pemangku kepentingan (Pasal 92 ayat [2]).

Dan pada tahap penyusunan Rancangan Perda, pembahasan Rancangan Perda, hingga Pengundangan Perda, Masyarakat berhak memberikan masukan secara lisan dan/atau tertulis. Dan masukan secara lisan dan/atau tertulis dimaksud, dapat dilakukan melalui:
a. rapat dengar pendapat umum;
b. kunjungan kerja;
c. sosialisasi; dan/atau
d. seminar, lokakarya, dan/atau diskusi. (Pasal 96 ayat [1] dan ayat [2]

\section{PENUTUP}

UU No 12/2011, yang khusus mengatur tentang Pembentukan Perda, telah mengimplementasikan beberapa unsur negara hukum dan demokrasi di dalamnya. Untuk prinsip negara hukum, tercermin dari adanya: asas legalitas dan kepastian hukum; hierarki peraturan perundang-undangan; dan perlindungan HAM. Untuk prinsip demokrasi, terutama, dicantumkannya asas "keterbukaan" dalam UU dimaksud.

Hal di atas, dapat ditempatkan dalam tataran ideal. Namun bagaimana dengan praktik Pembentukan Perda itu sendiri? Bukan lagi rahasia umum, bahwa Perda sekarang ini begitu banyak dibatalkan oleh pemerintah pusat. Hemat penulis, salah satu faktornya, yaitu "asas keterbukaan" tidak dijalankan dengan baik.

Tidak adanya transparansi dalam melibatkan masyarakat yang berkepentingan atas Perda, dan juga tidak dilakukan eksaminasi publik lewat perguruan tinggi, maka kolusi atau permainan uang tidak mustahil terjadi di dalamnya. Ini semua demi memenangkan pihak yang punya kepentingan besar atas Perda dimaksud. Jadi janganlah heran kalau banyak Perda dibatalkan dengan pertimbangan bertentangan dengan peraturan di atasnya, serta bertentangan dengan kepentingan umum.

UU No 12/2011 (termasuk pula UU yang lama, yakni UU No 10/2004), tetap mencantumkan asas "keterbukaan" dalam Pembentukan Perda. Namun, tak ada sanksi administratif yang tegas, bila hal itu diabaikan. Untuk penyempurnaan UU No 12/2011 ke depan, seyogyanya, salah satu alasan untuk membatalkan Perda oleh pemerintah pusat, adalah, tidak dijalankannya asas "keterbukaan" dimaksud.

Bila hal-hal di atas dapat direalisasikan, maka harapan untuk menegakkan "prinsip 
asas negara hukum dan demokrasi" di negara kita, bukan hanya terimplementasi dalam Law in Books, tapi juga dalam Law in Action.

\section{Daftar Pustaka}

\section{Buku, Makalah, Diktat, dan Kamus}

Astawa, I Gde Pantja dan Suprin Na'a, Dinamika Hukum dan Ilmu Perundang-Undangan Di Indonesia, Bandung: PT. Alumni, 2008.

Hadjon, Philipus M., Keterbukaan Pemerintah dan Tanggung Gugat Pemerintah, Makalah Seminar Hukum Nasional ke-VI, tema Reformasi Hukum Menuju Masyarakat Madani, Jakarta: Badan Pembinaan Hukum Nasional Departemen Kehakiman R.I, 12-15 Oktober 1999.

, Perlindungan Hukum Bagi Rakyat di Indonesia, Surabaya: Bina Ilmu 1987.

Indroharto, "Perbuatan Pemerintah Menurut Hukum Publik dan Hukum Perdata" Bahan

Kuliah/Diktat pada Program Pendidikan Lanjutan Ilmu Hukum Bidang PTUN, Universitas Indonesia, Jakarta.

Kesowo, Bambang, Implementasi Prinsip Supremasi Hukum dalam Berbagai Produk Hukum Nasional, Makalah Temu Ilmiah ISMAHI, Unhas, Makassar, 25 Oktober, 1994.

Poerwadarminta, W.J.S., Kamus Umum Bahasa Indonesia, Edisi Ketiga, Cet. 4, Jakarta: Balai Pustaka, Jakarta, 2007.

Seno, Adji Oemar, Seminar Ketatanegaraan Undang-Undang Dasar 1945, Jakarta: PT. Seruling Masa, 1966.

Saragih, Bintan R Peranan DPR GR Periode 1965-1971 dalam Menegakkan Ketatanegaraan yang Konstitusional Berdasarkan UUD 1945, Disertasi, Bandung: Universitas Padjadjaran, 1991.

Soemantri, Sri, Perbandingan Antar Hukum Tata Negara, Bandung: Alumni, 1971.

Wahjono, Padmo, Ilmu Negara Suatu Sistematik dan Penjelasan 14 Teori Ilmu Negara dari Jellinek, Jakarta: Melati Study Group, 1977.

\section{Majalah dan Koran}

Harian Mercusuar 23 September 2011

Laudoe, J.Z., Judicial Review: Sistem Perlindungan Hukum Terhadap tindakan Penguasa, Majalah Varia Peradilan, No. 84/Tahun IX/Sep.1995; 